\title{
EĞİTIMDE TOPLAM KALITE YÖNETIMI
}

\author{
Uzman Gülcan Numanoğlu \\ Uzman, Ankara Üniversitesi Eğitim Bilimleri Fakültesi \\ Bilgisayar ve Öğretim Teknolojileri Öğretmenliği Bölümü
}

\begin{abstract}
ÖZET
Yirminci yüzyılın başlarında bilimsel boyut kazanmaya başlayan yönetim kavramı, disiplinlerarası bir yaklaşımla çok kısa bir sürede gelişserek, 1990'l yılların başlarından itibaren ülkemizde de anılmaya bașlayan Toplam Kalite Yönetimi (TKY) anlayışını doğurmuştur.

Bu makalede de TKY'den balısedilerek, günümüzde en önemli hizmet sektörlerinden biri olarak kabul edilen eğitimde TKY anlayışııın "müşsteri" kavramı üzerinde biçimlenme şekli irdelenmeye çalışılacaktur.
\end{abstract}

\begin{abstract}
The concept of management becoming more scientific of the beginning of the 20 th. Century has advenced more expressly because of its accompanying an interdisiplinary approach. The same development has brought about the emergence of the conception of Total Quality Management in Turkey since the begining years of 1990's.

The aim of this study thuo, is to try to examine how the conception of TQM for education lof which considered nowadays as one of the pionering service sector) can be grounded within the concept of "client".
\end{abstract}

\section{Giriş}

Günümüzde teknolojik alandaki hızlı gelişmelerle birlikte bilimselleşme, küreselleşme ve yerelleşme çağımızdaki temel kavramlar olarak karşımıza çıkmaktadır. Çağdaş bilim ve teknoloji alanındaki gelişmelerle birlikte uluslararası rekabete açılma ve küreselleșme, uluslararası iliş̧kilerin gelişmesine ve toplumsal yaşamın çok hızlı değişmesine neden olmaktadır. Toplumsal yaşamdaki bu değişmelere paralel olarak uluslararası iliş̧ilerdeki artış evrensel düzeyde "entegrasyon" kavramını gündeme getirmiştir. Bu gelişim ise örgüt ve örgütler arası ilişkilere yeni boyutlar kazandırmıştır. Çünkü örgütte entegrasyonun sağlanabilmesi insanda kalite ve mükemmelliği yükseltme, belli standartlar çerçevesinde performansını geliștirebilme ihtiyacını doğurmuştur. Tüm bu ihtiyaçlar örgütsel ilişkileri ve yönetim tekniklerini etkilemektedir. Buna bağlı olarak da çalışı koşulları. yönetim ve çalışanlara dair yeni hedef ve politikalar gündeme gelmektedir.

Örgüt içerisinde yöneticiden en alt kademede çalışanlara kadar yapılan iş, çalışma ortamı, çalışanlar arası ilişkiler, uluslararası normlar diğer sektörlerdeki gelişim ve değişimler, statüler ve simgeler çalıșanlanı yönlendirmekte, örgütlerde çalıșanlardan yeni iş profilleri istemektedirler. Bu etki ve istekler mal ve hizmet üretimindeki niteliği, verimliliği, kaliteyi ve örgütün sürekliliğini etkilemektedir.

Eğitim kurumları da örgütler olarak bu değişimden etkilenecek ve eğitimin, toplumsal yaşamdaki değişimleri toplum için daha iyiye götürme ya da bu değișimlerde gelișme kaydedebilme rol ve sorumluluğu giderek önem kazanmaktadır.

Öğrenciyi dışarıda bırakan müfredat merkezli eğitim anlayışı, sınıf mevcutlarının kalabalıklığı, ikili ögrretim uygulaması, ders içeriklerinin öğrenci ilgi ve yeteneklerine uygun olmaması, eğitim ve ögretimin ezberci yaklaşımla yapılması, öğretmenlerin yetiştirilme aşamasındaki aksaklıklar, eğitim araçlarının kalite ve miktar yönünden azlığı gibi nedenler maliyeti durmadan yükselen eğitim harcamalarına yol açmakta, harcamaların verimsiz ve etkisizliğinin büyük boyutlara ulaşması da eğitim alanında ciddi arayışları ortaya çıkarmaktadır.

Yıllardan beri süregelen çözüm arayışları eğitimde kaliteyi yakalamada yeterli olamamıştır. $\mathrm{Bu}$ nedenle eğitim sorunlarına yeni bir felsefe ve anlayışla yaklaşma zorunluluğu ortaya çıkmıştır. Bu yaklaşım Toplam Kalite Yönetimi (TKY) olabilir. 


\section{Toplam Kalite Yönetimi}

TKY, W.Edwars Deming, Joseph M.Juran, Armand V.Feigenbaum ve Kaoru Ishikawa'nın öncülüğünü yaptığı 1990'lı yılların başından itibaren gelişen ve oldukça ilgi gören bir yaklaşımdır (Şișman, 1997, 61; Altıntaş, 1998, 37). TKY'de, örgütsel açıdan toplam sözcüğü, grubun bütünlüğünü, üretim sürecine tüm üyelerin birlikte katılmasını; kalite sözcüğü, ürünün veya hizmetin önceden belirlenen amaç ve standartlara uygun olarak üretilmesini; yönetim sözcủgü ise, üretilen ürün veya hizmetin tüm üyelerin kabul ettiği bir yönetim ve liderlik sistemi içerisinde üretilmesini ifade etmektedir (Şişman, 1997, 61).

TKY, bir işletmenin rekabet gücünü, verimlilik ve esnekliğini, her kademede çalışan personeli ve her faaliyeti dikkate alarak planlayan ve organize eden, etkili olabilmesi için örgütteki tüm personelin katılımının sağlandığı bir yaklaşımdır (İge, 1997, 6; Peker, 1994, 65). TKY örgüt yönetiminde ve çalışanlarda tutum değişimini gerektirmektedir (Balcı, 2000, 66). Bu anlayışta temel amaç; üretim sürecine örgütün her kademesindeki bireyin gönüllü katılımını sağlayarak, tüm işletme süreçlerinin geliştirilmesi ile müşteri memnuniyetini optimum seviyeye çıkarma ve böylece daha az maliyetle daha kaliteli ürün ortaya çıkarmaktır (Şişıman, 1997, 61).

TKY öncelikle endüstrideki işletmeler tarafından ele alınmıştır. Daha sonra hizmet sektöründe kendine yer edinerek sağlıkta, bankacılıkta, otellerde, lokantalarda, eğitimde Toplam Kalite (TK) yaklaşımları uygulanmaya çalışılmıştır (Bozkurt, 1997, 4).

Kalite anlayışı, Amerika'nın tanınmıș istatistikçisi olan Deming'in II. Dünya Savaşı'ndan sonra Japonya'yı ziyareti sırasında üst düzey yöneticilere, yönetimin görevleri ve sorumlulukları hakkında verdiği bir dizi konferans ile gündeme gelmiştir. Burada Deming'in mesajı "yönetimde temel fark yaratılmalıdır" ifadesidir. Deming bu konferanslarıyla Japon piyasasının başarısında "Deming Ödülü" olarak yerini almıștır (Aguayo, 1994, 17).

Deming bugünkü anlamıyla TKY'nin de birçok kavramını içine alan; vizyon sahibi liderlik, iç ve dış iletişim, öğrenme, süreç yönetimi, sürekli geliştirme, çalışanların katılımı, müşteri tatmini gibi konular üzerinde durarak yöneticiler için yol gösterici olan 14 ilke üzerinde durmuştur (Demirdöğen, 1994, 49; Köseoğlu, 1997, 4). Ayrıca kalite gelișimine sistematik bir yaklaşım getirmiştir. Ona göre ürün ya da hizmetlerin geliștirilmesi için amaçların değişmezliği önemlidir. Ayrıca üretimin kalitesinde çalışılan alan konusunda derin bilgi sahibi olmak ve istatistiksel analiz yöntemlerini kullanmak gerekliliğini savunmaktadır (TSE, 1996, 5).

Deming'in arkasından Japonya'ya çağrılan TKY öncülerinden olan Joseph M.Juran ise kalitenin; kalite planlaması, kalite kontrol ve kalite geliştirme aşamalarından sonra elde edileceğini savunmakla birlikte üst yönetimin liderliğini ve eğitimin gerekliliğini vurgulayarak, müşteri kavramındaki iç ve dış müşteri ayrımını gündeme getirmiştir. Juran'ında kalite geliştirme konusunda 10 ilkesi bulunmaktadır (TSE, 1996, 4).

Armand V.Feigenbaum ise Toplam Kalite Kontrol (TKK) kavramının isim babası olarak bilinmektedir; TKK'nın başarısı için 10 nokta üzerinde durmaktadır. Kısaca kalitenin; tüm örgüt düzeyinde bir süreç ve yönetim biçimi olduğunu, sürekli gelişmeyi gerektirdiğini, örgütün etkileşim içinde olduğu herkesin ve tüm sistemin katılımıyla uygulanabilir olduğunu söylemektedir (Elif, 1999, 55-56).

Kaoru İshikawa, Japonya'da Kalite Kontrol Çemberleri ve Kalite Kontrol faaliyetlerinin gelişmesinde öncülük etmiş birisidir. Japonya'da TKK hareketinin karakteristik özelliklerini şu şekilde sıralamaktadır (TSE, 1996, 6): TKK'ya herkesin katılımını sağlama, mesleki eğitim ve üretime önem verme, kalite kontrol çemberleri çalışmalarına önem verme, kalite kontrol denetimlerine önem verme, istatistiksel yöntemleri uygulama ve TKK'nın ülke çapında tanıtılması.

Philip Crosby ise, TKY'de hataların \%80'inin yönetimden, \%20'sinin de çalışanlardan kaynaklandığı görüşündedir. Bu nedenle de Crosby üst yönetimin ve müdürlerin eğitimine önem vermektedir. Crosby'e göre kalite: Mükemmellik değil ihtiyaçlara uygunluktur. Kalite hatalan önlemedir. Çalışmada sıfır hata standaıt olmalıdır. Crosby'de Deming gibi kalitenin göstergesi olan maliyeti azaltmak için 14 ilkeli bir yaklaşım ileri sürmekte ve sonuçta kalitenin sonu olmayan bir gelişmeyi içerdiğini belirtmektedir (TSE, 1996, 4).

Yukarıda bahsedilen TKY öncülerinin görüşlerinden de anlaşılacağı üzere bu yaklaşımla klasik yönetim-yönetici ve çalışan anlayışı tümüyle değişmektedir.

TKY konusunda Crosby, Feigenbaum, Deming, Shiba, Oakland, Kelly, Ishikawa, Kanji, Lammermeyr gibi literatüre katkıda bulunanların çoğu aşağıdaki özellikler üzerinde uzlaşma sağlamışlardır (Köseoğlu ve diğ., 1994, 22): TKY müșteri odaklıdır, TKY örgütün uzun dönemli taahhüdünü gerektirir, TKY yönetim hamlesidir, 
TKY'de insan önemlidir ve amacı kaliteye dayalı kültür üretmektir, TKY'nin örgüt çalışanlarının genel bir amaç için motivasyonuna ihtiyacı vardır, TKY'de ekiple çalışma önemlidir, müşteri tatmini için sürekli çalışma gereklidir. Bunun için müşteri beklentileri üzerine odaklaşılır.

Görüldüğü gibi TKY yönetim-çalışanlar ve müşteriler üzerinde odaklaşma ve tüm örgütün uzun dönemli bağlılığını içermektedir. Burada önemli bir anahtar da müşteri kavramıdır. Kaliteyi yakalayabilmek için müşteri istekleri araştırılıp, sürekli değerlendirilmelidir. Bunun için de çalışanların belirlenen genel amacı kabul edip, sahiplendikten sonra sorumluluk almaları gerekmektedir.

Tüm bunlar yapıldığında TKY için; liderlik, üst yönetimin bağlılığı, müșteri odaklılığı (memnuniyeti), toplam katılımcılık, sistematik analiz gelişim faktörleri ve bu faktörleri oluşturan unsurları kapsayan çalışmalar yapılması ve sürekli değerlendirilerek aksayan yönlerin giderilmesi gerekmektedir (Bozkurt, 1997, 4).

Liderlik bir kurumda, kurumun motor gücüdür diyebiliriz. Liderlik olmadan ve liderin TKY konusunda olumlu bir motivasyonu olmadan bu sürecin tamamlanması oldukça zordur. Bu nedenle liderin ya da yöneticinin bu ișe duyduğu inanç çok önemlidir. Öte yandan üst yönetimin bağlılığı da liderin takındığı tutum ve tavırlarla doğru orantılı olarak ilerleyecektir. Onlar motive oldukça diğer çalışanlara tutum ve tavırları ile ulaşmak daha kolay olacaktır. $\mathrm{Bu}$ zincirleme reaksiyonda müșteri odaklıığını sağlamak da çalışanların bir görevi olduğuna göre müșteri gereksinimlerinin farkındalığının sürekliliğinin sağlanması da zorunludur. Bunun için de en üst kademeden en alt kademeye kadar tüm çalıșanlar sürece katılmalı, onların fikirlerinin dikkate alındığı belirtilmeli, karar mekanizmalarına katıldıkları hissettirilmelidir ki böylece kurumda toplam katılımcılık sağlanarak, tüım birimler arasında uyumlu bir çalışma ortamı sağlanabilmelidir. Bu şekilde kurum tüm çalışanların emeği ile basamakları tırmanırken ortaya çıkan enerji tüm çalışanlar tarafından paylaşılacaktır. Bu da beraberinde kurum içindeki iletişim sürecinde geri bildirimin oluşmasını sağlayarak, yapılan tüm çalışmaların gerektiği zaman analiz ve değerlendirilmesini kolaylaştıracaktır. Yapılan bu değerlendirmeler ile nerede, ne zaman, nasıl bir aksaklığın oluştuğu ortaya çıkarılarak, gerekli düzeltmeler yapılabilecek ve kurumun TKY için değişikliklere uyum sürecindeki karar mekanizmaları daha kolay işletilebilecektir.

\section{Eğitimde Kalite}

"Eğitim, bireyin içinde bulunduğu çevre ile sürekli etkileşimde bulunması sonucu elde ettiği kalıcı izlenimleri davranıșa dönüştürme süreci" (Alkan, 1994, 41) ya da "bireye çevresinde olan değişimleri karşılayabilecek ve değiştirecek biçimde yeni davranıșlar kazandırma süreci" (Ünal, 1997, 5) ya da "bireyi şekillendirme, bilgilendirip biçimlendirme yeni becerilerle donanımlı kılma, tutum ve davranışlarında kalıcı ve istendik değişiklikler sağlama etkinliği" (Özgen, 1998, 4) olarak tanımlanabilir.

Tüm bu tanımlardan anlaşılacağı üzere eğitimde ögrenilebilir insan davranıșlarından bahsedilmektedir. O halde eğitim örgütleri; her bireyi toplumsal gelişime yarar sağlayacak biçimde değerlendirmeyi esas alan, bireyi kendi değerlerine sahip çıkacak, onları en iyi şekilde tanıyıp, geliştirebilecek bir bilince kavuşturmayı amaçlamalı ve bunları bireye kazandırabilecek nitelikte olmalıdır. Çünkü birey yaşamında en verimli, alıcı, ögrenen olduğu zamanda çağdaș eğitime teslim edilmekte ve geleceğinin șekillendirilmesi sorumluluğu ve yetkisi eğitim kurumlarına devredilmektedir (Serter, 1997, 55, 63).

Ulusal ve uluslararası ortamda her alanda rekabetin artması ile yönetim sistemlerinin amacı, kurumun kendi alanında lider olabilmesi için mal veya hizmet üretiminde rekabet gücünü yükseltmektir. Bu amaca ulaşmak için en önemli kaynak nitelikli insan gücüdür. Nitelikli insan gücünün yetiștirildiği eğitim kurumlarının sağladığı hizmet kalitesi de tüm sektörlerin kalitesini etkileyen temel unsur ólarak karşımıza çıkmaktadır (Peker, 1996, 25). "Eğitim kurumunun çıktılarını kullanan ve ona girdiler sağlayan diğer çevresel faktörler veya genel anlamda toplum, eğitim örgütlerini de yenileşmeye zorlamaktadır " (Özdemir, 1995, 385).

$\mathrm{Bu}$ bağlamda da günümüzün rekabetçi dünyasında, ancak ve ancak yüksek kalitede ürün ve hizmet üreten örgütlerin bașarı ve gelișmelerini sürdürebileceği (Glasser, 1999, 4) gerçeğinden yola cıkarak; zaman, zihin, beden, ruh gücü ve maddi kaynakların kullanımının israf edilmeden gerçekleștirilmesini sağlayabilecek (Serter, 1997, 70) bir eğitim anlayıșı bizi sürekli değişimin dinamik bir yapı taşı olan "Eğitimde Kalite" kavramına götürecektir.

Pek çok ülkede tartışılmakta olan TKY'nin örgüte dinamizm getirdiği, personelin birbirlerine ve örgütün amaçlarına karşı ilgi ve duyarlılıklarını artırdığı görülmektedir (Aksu, 1995, 206). Özellikle eğitim kurumlarında da etkililiği artırmada uygulanma şansının olduğu belirtilmektedir. 
TKY'nin eğitim sistemine uygulanması ile yönetici, öğretmen, programlar, eğitim ortamları, yöntemteknik, ögrenme teknolojileri vb. girdilerin kalitesi önem kazanacaktır. Çünkü ancak kaliteli girdiden kaliteli çıktı elde edilebileceği bilinmektedir (Aksu, 1995, 208; Peker, 1996, 31). Eğitim sisteminde birçok sorunların yaşandığı Türkiye'de okul sistemi içinde süreç, ürün ve hizmet boyutlarında TKY'den yararlanılabileceği düşünülmektedir. Bu șekilde okullar bilgi üreten ve ürettiğini topluma kazandıran merkezler olacaklardır.

Eğitimde kalite; üretilen eğitim hizmetlerinin toplumun beklentisine uygunluğu veya toplumun beklentilerini karșılama derecesi (Çelik, 1996, 349) olarak tanımlanabileceği gibi eğitimin amaç ve işlevlerini gerçekleştirme veya başarma biçim ve derecesi olarak da tanımlanabilir. Alkan $(1994,42)$ ise bu kavramı "yüksek düzeyde davranış üretme; sürekli gelişim ve mükemmeliyet" olarak tanımlamaktadır.

Genel olarak bakıldığında eğitim kurumu verdiği hizmetle, yetiştirmeyi amaçladığı insan tipine özgü bilgi ve becerileri öğrenciye kazandırabiliyorsa ve öğrenci onu hayatın içinde ișlevsel olarak kullanabiliyorsa, bu eğitim kalitelidir denilebilir.

Eğitimde daha iyiye, daha güzele varmak için birçok çalıșmalar yapılmaktadır. Ancak yapılan bu çalışmaların başarıya ulaşmasında eğitimin yukarıda belirtilen fonksiyonunu yerine getirebilmesi için esnek bir model içerisinde yapılanarak sistemleștirme, nitelikli öğretim kadrosu ve çağdaş gereksinimlerin dikkate alınmasının önemi çok büyüktür. Ayrıca eğitimde kalite çalıșmaları geçmişte olduğu gibi gelecekte de önemli olmaya devam edecektir (Cafoğlu, 1996, 12).

Alkan (1994, 42), eğitimde kalitenin öneminin; çağdaş bilim ve teknoloji alanındaki gelișmeler.uluslararası ilișkilerdeki artıș, sadece eğitimde kazanılabilecek bilgi ve becerilere olan gereksinim. yaşama uyum sağlamak için iyi bir üretici ve akıllı, bilgili tüketici olma gereksinimi gibi nedenlerle arttığını belirtmektedir.

Eğitimde kalite anlayıșının yerleşmesinde öncelikle bu konudaki kararlılık ve samimiyetin önemli bir yeri olduğu unutulmamalıdır. Yukarıda belirttiğimiz TKY yaklașımından da anlașılacağı üzere kalite düşünce aşamasında başlayıp, tasarımla uygulamaya yön veren bir kavram olarak karşımıza çıkmaktadır. Bu noktada öncelikle sorunun kabulü önemli bir konudur. Çünkü sorunu açıklıkla kabul etmeyen birisi ne kendisi için ne de bir başkası için örnek davranıș sergileyemeyecektir. Ayrıca elde edilen sonucun sürekliliğinin sağlanması, ancak ve ancak kişiler arasındaki ortak görüșün herkes tarafından kabulüne bağlıdır. Ortak görüşün ve bu bağlamda sürekli gelişimin sağlanabilmesi ise uzun zaman alacağından inanç ve sabır bu noktada çok önemli insan özellikleridir. Bu adımlardan birisinde doğabilecek bir eksiklik tüm sistemi etkileyerek, tasarım aşamasında başarısızlığı ve ardından uygulamadaki bașarısızlığı beraberinde getirecektir.

Eğitimde kaliteyi etkileyen çeşitli faktörler bulunmaktadır. Bunlar iç ve diş faktörler olmak üzere iki basslık altında ele alınabilir (Ünal, 1997, 5):

\begin{tabular}{l} 
İc Faktörler \\
\hline Yönetici \\
Öğretmen \\
Ögrrenci \\
Eğitim Programları \\
Yöntemler \\
Eğitim Ortamı. \\
Diğer Çalışanlar
\end{tabular}

Dis Faktörler

Hizmet Alanlar Sanayi Üretim Alanları Teknolojik Gelişmeler Toplumsal İtiyaçlar Aileler Üst Eggitim Kurumları

Bir okulda yöneticinin, öğretmenin, öğrencinin, programların, ortamın vb. diğer faktörlerin eğitimde kaliteyi sağlayabilmek açısından nicel ve nitel yönlerinin önemli olduğu söylenebilir. Okulda yeterli sayıda ögretmen yoksa, ortam ögrrencilerin etkili kullanımına uygun değilse (laboratuar, derslik, okul binası, ısınma, aydınlatma, kütüphane vb.) böyle bir mekan tasarımında boș geçen dersler ile ögrenci mutlu olmayacak ve başarı sağlanamayacaktır. Bu da beraberinde düşük başarıdüşük kalite doğurgusunu getirecektir. Böyle bir okuldan düşük kalite ile mezun olan öğrenci yeterli bilgi ve becerisi olmadığından dolayı iş hayatında ileri teknoloji ürünlerinin kullanıldığı bir atmosferde uyum problemi ile karşılaşacak, belki de bir üst eğitim kurumuna giremeyecek, ailesinin okuldan beklediği başarıyı sağlayamayacaktır. Oysa tüm bunların aksine yönetici, öğretmen, öğrenci ve diğer çalıșanların mutlu olduğu bir ortamda hizınet sunmaları veya hizmeti almaları kaliteyi artıracağı gibi okul bitiminde ögrencilerin iş bulmasında veya bir üst eğitime geçişlerinde olumlu sonuçlar doğuracaktır.

TKY anlayışına göre eğitimde ele alınan iç ve dıș faktörler sırasıyla iç ve dıș müșteriler olarak kavramsallaştırıldığında, ürün veya hizmet alanlardan kurum içinde olanlara "iç müşteri", kurum dıșında olanlara da "dıș müșteri" adı verilmektedir. (Cafoğlu, 1996, 113; Ceylan, 1997, 25). Örneğin bir eğitim kurumunda karşılıklı hizmet alış veriși içinde bulunan kișiler ya da birimler hizmetin sunumuna göre hizmet alan-hizmet veren konumundadır. Buna göre; öğrencileri, akademik personeli ve diğer çalıșanları eğitimde iç müșteri olarak ele almak mümkündür. Çünkü kurum içinde 
belli bir hizmeti diğer çalıșanlardan veya birimlerden almaktadırlar. Örneğin; öğrenciler açısından konuya baktığımızda eğitim kurumunun içinde öğretmenden hizmet alan konumunda oldukları için iç müşteri; çocuğunu bir eğitim kurumunda okutan aile hizmeti dolaylı olarak çocuğu vasıtasıyla- kurumun dışında aldığından dış müșteri konumundadır (Ceylan, 1997, 24-25). Bunları daha da somuta indirgediğimiz zaman karşımıza şöyle bir tablo çıkmaktadır.

\begin{tabular}{ll} 
İc Müsteriler & Dıs Müssteriler \\
\hline Yönetici & Aile \\
Öğrenci & Toplum \\
Akademik Personel & İ Sü Dünyası \\
Diğer Çalışanlar & Ûst Eğitim Kurumu
\end{tabular}

Eğitim kurumları kendi hedef, strateji ve planları doğrultusunda iç ve dış müşterilerin ihtiyaçlarını karşılamayı hedeflemektedir. Eğitim kurumundaki iç müşterilerin, kendilerinin ve dıș müşterilerin beklediği seviyede kaliteli bir eğitime ulaşabilmeleri için; ekip çalıșması yapma, yaratıcı çalışmalarda bulunma, motivasyonu sağlama, iyi iletişim kurma, işbirliği yapma, sorumlulùk alma, gerekli ortam/ortamları düzenleme, sürekli araştırma-geliştirme çalışması yapma, yeni bilgi ve becerilerle donanık olma gibi faaliyetleri bir arada ve uyum içinde yürütmeleri gerekmektedir (Ünal, 1997, 5). Müşteri memnuniyeti günümüzde her geçen gün önem kazanan ve aynı zamanda bitiși olmayan bir yarıştan farksızdır. Çünkü piyasa koşulları içerisinde hem özel hem de devlet okullarının varlığı ve her ikisi arasındaki nitel ve nicel farklılıklar eğitim kurumunun varlığını sürdürebilmesi ve müșteri bulabilmesi için, okulların rekabet ortamı içerisine sokulmasını kaçınılmaz kılmaktadır. Rekabet ortamında yaşayabilmek için eğitim kurumunun kendine çeki düzen vererek, çıktının elde ediliş sürecini değerlendirmesi ve bu şekilde hataların anında giderilmesi ile müșteri memnuniyetini sağlamasına bağlıdır. Bugün $(A)$ işi ile memnun olan müșteri yarın $(A+B)$ iși ile bile memnun olmayabilir. Ancak burada önemli bir nokta TKY'de olduğu gibi müşteri memnuniyetini sağlarken öncelikle kurum içinde çalışanların memnuniyetinin sağlanması yani insan ögesinin göz ardı edilmemesi gereklidir. Çünkü işini yapmaktan memnun olan insanlar (eğitim kurumlarında yönetici, öğretmen, diğer personel) en üst çabayı sarf edecekler, bu da bu kurumdan beklentisi olan kiși ve kurumları memnun edecektir. Çünkü çıktı kaliteli olacaktır. Örneğin; okuldan mezun olan bir ögrenci, ailesinin beklentisi gibi bir üst eğitim kurumuna geçişte başarılı bir yer edinirse bu ișten aile de ögrenci de memnun kalacaktır.
TKY uygulaması; yönetim, öğrenciler ve öğrenme açısından eğitime bazı katkılar getirmektedir (Tok, 2001, 111). Yönetim açısından konuya baktığımızda; okulların iyileştirilmesine yardımcı olacağı ve her türlü savurganlığın önüne geçilebileceği söylenebilir (Tok, 2001, 111). Öğrenciler açısından ise, TKY uygulaması ögrencilerin kendi bireysel yeterliklerini geliştirmelerini, bilimsel düşünebilen bireyler olarak yetişmelerini sağlamakta ve öğrenme açısından da liderliği geliștirmesi, yaratıcılığı ön plana çıkarması, başarısız olma korkusunu engellemesi nedeniyle ögrenmeden zevk almayı sağlaması önemli katkılardır (Hergüner, 1998, 19).

Tok'un (2001) yapmış olduğu araştırmaya göre TKY'nin eğitime uygulanabilirliği öğretmen ve yönetici görüşleri ile desteklenımiștir. Araștırmada TKY'nin eğitimde uygulanabilirliği konusunda; okulların kaynak yaratma ve kullanımı konusunda sıkıntıları olmadığı, okulda düşünce paylaşımı konusunda demokratik bir ortam olduğu, eğitimin niteliğinin artıșına katkıda bulunanların ödüllendirildiği, öğrencilerin bireysel öğrenme kapasitelerinin dikkate alındığı, yaratıcılıklarının geliştirilebilmesi için gerekli olanakların sağlandığı, kişisel becerilerin ortaya çıkarılabilmesi için ögrencilerin teșvik edildiği, bireysel becerilerin dikkate alınarak ödev. verildiği, öğrenci merkezli öğretim yapıldığı, uygulanan ögrenme stratejilerinin öğrenmeyi desteklediği gibi sonuçlar çıkmıştır:

\section{Eğitimde Toplam Kalite Yönetiminin} Müşteriye Yansımalar

TKY'nin temel felsefesini oluşturan ana değerler olan; liderlik, üst yönetimin bağlılı̆̆ı, müșteri memnuniyeti, toplam katılımcılık. sistematik analiz (Bozkurt, 1997, 4) eğitimde nasıl bir görünüm arz etmektedir? Bu konu yazının bundan sonraki kısmında iç müşterilerin öğrenmeye katkıları-etkileri boyutunda ele alınarak incelenecektir.

Yönetici:Ülkelerin bilgi toplumuna ulașması sonucu meydana gelen bilimsel ve teknolojik gelişmeler, örgüt yapısında ve çalıșanların görev ve sorumluluk bilinçlerinde önemli değişikliklere yol açmaktadır. Eğitim örgütleri ve yöneticiler de bu değişim süreci dışında düşünülemezler. Eğitim yöneticisi sadece programların düzenl yürütülmesini denetleyen, öğretmen-öğrenci ilişkilerini düzenleyen kişi değildir. Okulda hem öğretmenleri hem de öğrencileri yöneten idareciler, kendilerini işlerine adamış, görev ve sorumluluk bilincine sahip insancıl kișiler olarak; öğrencilerin çalışmalarına kaliteyi yansıtmada üzerlerine düșen görevi. kendi rollerindeki değişimlere en kısa sürede adapte olarak yerine getireceklerdir (Glasser, 1999. 
4). Çünkü bu değişime adapte olan yöneticiler öncelikle kendi altında çalıșan sınıf yöneticileri olan ögretmenleri ne kadar iyi yönetirlerse bu zincirleme reaksiyonun devamını sağlayacaklardır.

TKY yaklaşımına göre en temel değişimin, üst yönetimde olması gerektiği anlaşılmaktadır. Bu da liderlik rolüyle TKY içinde yer almaktadır. $\mathrm{O}$ halde eğitimde TKY içinde yöneticinin liderliği ve bu konudaki olumlu yaklaşımı, inancı ve üst yönetimin bağlılığı önemli bir yer tutmaktadır. Eğitimde TKY'nin uygulanması, iyi yönetim-iyi öğretim bileșenini beraberinde getirecektir. Glasser'inde (1999, 15) dediği gibi "kalite için yönetmek, zorlayıcı olmayan yeni bir yönetim yaklaşımı gerektirir ki, bu da liderce yönetimdir".

Yöneticinin örgüte yön verirken, ortak paydaya yönelik olarak, ortak bakış açısını tüm çalışanlarına kazandırması gerekmektedir. Liderlik sürecinin iki önemli temeli planlama ve motivasyondur (Bozkurt, 1997, 4). Bu noktada yöneticinin; iyi bir planlama ile gelecekte ulaşılmak istenen durumu ortaya koyması, ögrenci, ögretmen ve diğer personeli için çalışılabilir bir mekan oluşturması ve herkesin okula gelmekten mutluluk duyacağı bir atmosfer yaratması, tüm çalışanları tarafından kabul edilecek kurum kültürǜ oluşturması, çalışanlarına karşı inisiyatif sahibi olması, baskıcı tutumla yönetimden vazgeçmesi, onları motive edecek ödüller koyması, etkileşim sürecine önem vermesi, işbirliği içinde takım çalıșmasını özendirmesi gibi aktif katılımcılığın gerektirdiği liderlik özelliklerine sahip olması gereklidir. Ancak burada katılımcılığın karar ve uygulama aşamalarında, tüm personelin formaliteden değil de gerçekten işe koşulabildiği oranda gerçekleștirilebileceği yönetici tarafından unutulmamalıdır. Örneğin; iki ayrı okul müdürü okullarının kalitesini artırmak istiyor. Bunun için (A) okulunun müdürü okuluna en son teknolojik ürünleri (bilgisayar, internet bağlantısı, video, tepegöz vb.) alıyor. İlk yıl bu ürünler alındığında ögretmen, ögrenci ve veliler çok memnun oluyor. Bu olanaklardan nasıl yararlanacaklarını planlıyorlar. Ancak hiçbiri bu teknolojik ürünleri kullanabilecek ve ögrrencilere rehberlik edebilecek bilgi ve becerilere sahip değil. Bir yıl daha geçtiğinde alınan araçların kilitli odalara hapsedildiği görülüyor. $\mathrm{Bu}$ arada (B) okulunun müdürü ise okulundaki aksayan her türlü hizmeti ortaya çıkarmak için öğretmen, öğrenci, veli ve diğer çalışanları ile birlikte bir proje geliştiriyor. İlk yıl bu projenin geliştirilmesi için olușturulan takım çalıșmaları ile onlara liderlik yaparak geçiriyor. Daha sonraki yıl bu çalışmalar uygulamaya geçirilerek sonuçlar değerlendiriliyor ve alınan geri bildirimlere göre düzenlemeler tekrar yapılıyor.
Bu çalışmalar ışığında (B) okulunun müdürü aktif katılımcı liderlik özelliklerini göstererek tüm personelini motive etmiş ve olumlu bir planlama ile onları takım çalıșmasına yönlendirmiştir. Bu şekilde okulundaki herkes mutlu olmuştur. Öte yandan okulda verilen eğitimin kalitesini yükseltmiş olmasına rağmen (A) okulunun müdürü klasik yönetim-yönetici anlayışıyla okulundaki hiçbir bireyi ișin içine katmadan, sorunu belirlemeden, planlama yapmadan emir komuta zinciri ile kendi belirlediği sorunu yine kendisi çözmeye çalıştığından, okulun ödeneklerini boşa harcayarak israfa neden olmuş ve kalitesiz bir eğitim örneği sergilemiştir.

Yöneticinin değişikliklere uyum yeteneği okul içindeki başarının devamında etkilidir. Ayrıca okulda sadece yönetici kadrosunda bulunan kişinin değil, önemli noktalarda görev yapan diğer kişilerin yani üst yönetimin amaçlara ulaşmayı destekleyici değerler kümesini yaratarak tüm değişimlere aktif katılımı, bağlılıkları ve uygun stratejiler izlemeleri değişimin sürekliliğini garanti altına alacaktır (Bozkurt, 1997, 4). Yöneticinin okulu için yapabileceği en iyi şey tüm değişim olaylarına aktif biçimde katılarak, altında çalışan öğretmen, öğrenci ve diğer personeline örnek olmasıdır. Sürekli gelişmeyi destekleyen ama değişime zorlamayan, ödüllendiren, personel niteliklerinin geliştirilmesi için çeşitli etkinliklerde bulunup çalışanlarının standartlarını yükseltmek için kalite kültürünü de içerecek biçimde onların faaliyette bulunabilecekleri daha uygun bir örgüt kültürü oluşturan ve girdi-çıktı arasında kalan örneğin; materyal hazırlama süreci, ortam hazırlama süreci, değerlendirme süreci vb. (Bozkurt, 1997, 22) süreç geliştirme çalışmalarında tüm çalışanlarına bağlılığı ve güvenini gösterebilen bir yönetici gerekli değişiklikleri belirleyip bunları uygulama aşamasına getirebilir. Bunun için de sürece dayalı bir yaklaşım izleyen TKY'de ekip çalıșması zincirin önemli halkalarından biri olacağı için okul yöneticileri bilgi, beceri ve yeteneklerini ilgili alanlarda geliştirmek zorunda kalacaklardır.

Eğitim yöneticisinin okulunu arzulanan
geleceğe taşımasında belirlediği vizyonun
paylaşılabilir olması ve bu bağlamda da tüm
personelinin okula "bizim" zihniyeti ile bakmasını
sağlaması eğitimde TKY yaklaşımında yöneticinin
diğer bir görevidir (Cafoğlu, 1996, 47). Ayrıca okul
yöneticisinin bir vizyonu olmadan, yöneticiler ve
diğer personel tarafından paylaşılan ortak değerler
olarak tanımlanan örgütsel misyonu (amacı)
oluşturması olanaksızdır. Çünkü vizyon, misyonun
temel belirleyicisidir. Yönetici belirlenen vizyon ve
misyon doğrultusunda kendisine bağlı olarak çalışan
tüm personelin rol ve görevlerini tanımlamalı,


yönetici-öğretmen-öğrenci-veli etkileşimini güçlendirmeli, okul ve ailenin çocuğun eğitimindeki rollerini tanımlamalı ve okul-çevre ilişkilerini yeniden düzenlemelidir (Korkut ve Korucu, 1998, 67). Yönetici liderlik konumunda öğretmen, öğrenci ve diğer personeli için olumlu motivasyonu engelleyen faktörleri ortadan kaldırmak için iletişim süreçlerini en iyi şekilde işletmeli, ödüllendirme sistemleri koymalı ve personeline bireysel çalışı yetkisini verebilmelidir.

$\mathrm{Bu}$ bağlamda okul yöneticisinin hedef ve gerçeklerini oluşturmada vizyon ve misyonun desteklenmesi ve tüm çalıșanlar tarafından paylaşılması önemli bir adımdır. Daha sonra bu hedef için atılacak stratejik adımlar ve yapılacak faaliyetlerin seçilip, projelerin geliştirilerek uygulamaya geçilmesi ve sonuçların değerlendirmelerle sürekli yenilenmesi gerekmektedir.

TKY'nin bir okulda yönetim açısından sağlayacağı yararları şöyle sıralayabiliriz (Hergüner, 1998, 19-20): Yönetim merkeziyetçilikten uzaklaşmaktadır, her okul kendi TKY yaklaşımını uygulayacağından kendi sorunlarını kendisi çözebilecektir, okullar bazında çözülemeyen sorunlar azalacaktır, okullar eğitim-öğretimle ilgili daha çok veri toplayıp değerlendirebilecektir, okuldaki sorunların çözüldüğünü gören öğretmen kendi katkılarının göz ardı edilmediğini düşündüğü için olumlu motivasyona sahip olacaktır, her düzeyde temsil yoluyla gerçekleştirilecek kararların uygulanması kolaylașacaktır.

Öğrenci: Eğitimin temel müşterileri hiç şüphesiz ki öğrencilerdir. Öğrenciler eğitim kurumlarına bir şeyler öğrenerek bir üst eğitim kademesine geçmek için veya is hayatına atılmak için gelmektedirler. $\mathrm{O}$ halde eğitim kurumları da ögrencilerin istek ve ihtiyaçlarına uygun olarak yapılanmalıdırlar. Bu da ancak TKY anlayışına göre toplam katılımcılık, müşteri memnuniyeti, sistematik analiz yolları ile yapılabilecektir.

Bilindiği üzere artık klasik eğitim anlayışı yerini modern eğitim anlayışına bırakımıștır. Klasik eğitim anlayışı öğrenci merkeziyetçiliğini yadsırken modern eğitim anlayışı tümüyle öğrenciyi merkeze alan bir yaklaşım benimsemektedir. Bunun sonucu olarak bireysel öğrenme yaklașımına dönük yöntem ve teknikler okullarda uygulamaya geçirilmektedir. $\mathrm{Bu}$ şekilde öğrenci ezbercilikten kurtarılarak, araştıran, problem çözme becerisine sahip, bilgiye ulaşabilen, yaratıcı bireyler haline getirilecektir.

Klasik eğitim anlayışında eğitim ve öğretimde yönetici-öğretmen-öğrenci sıralaması bulunurken TKY'ye göre bu sıra ögrenci-öğretmen-yönetici olarak değișmektedir. Bu sıralamada öğrenciye öğrenme sorumluluğu aktarılarak. öğretmenin öğretıne sorumluluğunda rehber olma görevi ön plana çıkmaktadır. Bu bağlamda TKY yaklaşımı öğrenciyi merkeze almaktadır.

Eğitim öğrencilere; bilgiyi aktarabilecek, yeteneklerini geliștirebilecek, profesyonel amaçlara yönlendirebilecek ve onları öğrenme işinde motive edebilecek șekilde örgütlenmelidir. Bu örgütlenınede ögrencilerin belli şeyleri neden öğrendiklerini anlamaları, bulundukları ortam ve konumdan dolayı duydukları memnuniyet, sınıf veya okul etkinliklerinde katılımcılığı beraberinde getirecektir.

Tüm öğrencilerin öğrenebileceği ve tüm öğretmenlerin öğretebileceği varsayımına dayalı olarak (Balcı, 1993, 12) ögrrencinin kendisini mutlu hissedeceği, bilgi iletişiminin yer aldığı, öğrencinin etkileşimde bulunduğu ve eğitim etkinliklerinin meydana geldiği bir eğitim ortamının oluşturulması onda ögrrenme arzusunu kamçılayarak, daha yaratıcı ve yapıcı olmasını sağlayacaktır (Alkan, 1994, 41). Ayrıca TK okullarında öğrenci başarısını etkileyen faktörler sadece öğretmen ve ortam değildir. En önemli faktörlerden birisi de optimum bir ögrenme ortamı hazırlanmasını sağlayan, tüm çalışanlarına okul kültürünü aşılayan ve öğretmenleri motive ederek öğretme sorumluluğunu tümüyle onlara bırakan okuldaki ögretim lideri konumundaki müdürdür (Balcı, 1993, 25).

Uygun bir eğitim ortamı hazırlanan okulda öğretmenler tarafından ögrencilerin kendi bireysel ve ögrrenme kapasitelerine uygun eğitim-öğretimin sürekliliǧinin sağlanması TKY anlayışına göre hem iç müșteriler "hem de dış müșteriler açısından memnuniyet verici sonuçlar doğuracaktır. Ögretmenlerin öğrencileri tanıma süreçlerinde; başarısız oldukları alanları değil de başarılı oldukları alanları ön plana çıkarmaları, öğrencilere kendi yeteneklerini algılama becerisini kazandırmaları, düşüncelerinin kendileri için ne kadar önemli olduğu fikrini kazandırmaları TK okulları için yetenek ve becerileri belirlenmiș kişiler olarak girdi sağlayacaktır (Cafoğlu, 1996, 134-135; Glasser, 1999, 119). Bunun için öğrenciye ait kayıtların tutulması TKY anlayışıyla yönetilen bir okulda belgelendirme açısından önemli bir konudur. Ayrıca bu belgeler vasıtasıyla yapılabilecek istatistiki analizler ile ögrenci başarısının sürekliliği için gerekli çalışmalar yapılabilir. TKY uygulaması ile öğrenciler, sorularının çözümünü gördükleri için her defasında başka bir soru soran, sosyal bir birey olmanın deneyimini yaşayabilen, kişisel bilgi ve beceri düzeyindeki yeterliklerini daha iyi tanıyıp kişilerarası yeterliklerini geliştirebilen, ekiple uyuın içinde çalışma alıșkanlığını kazanabilen, baskı ve 
tehditten uzak bir sınıf ortamı isteyebilen ve lider özellikleri taşıyan, bilimsel düșünebilen bireyler olarak yetişeceklerdir (Hergüner, 1997, 20).

Akademik Personel (Öğretmenler): Bir eğitim kurumu olarak okul, sosyal bir sistem olarak ele alındığında; öğretmen, yönetici, müfettiş, öğrenci ve velilerin bu sistemin amacına ulașmasında üzerlerine düşen görevleri veya belirli olan rollerini gerçekleştirmeleri beklenir (Özdemir, 1996, 69).

Toplumsal gelişim ve değișimler sonucunda okuldan beklenen rollerde de farklılıklar ortaya çıktığı gibi öğrenmenin yapısında meydana gelen değişiklikler nedeniyle de öğretmenin görev tanımında değişimler meydana gelmektedir. Eğitimdeki yenileşmelerin başarısı büyük ölçüde ögretmenlerin sistemi benimsemesi ve sistemin gerektirdiği bilgi ve beceri düzeyinde olmalarına bağlıdır.

Kaliteli bir toplumun oluşturulmasında, eğitim sürecinde çıktının kaliteli olmasını sağlayacak kişi hiç şüphesiz ki öğretmendir. Öğretmen TKY'ye geçiş de sınıf ortamındaki uygulamalarında not ile tehdide son vermeli, iletişim kanallarını sürekli açık bırakmalı ve öncelikle çalışan ve çalışmayanlar olarak ayırdığı öğrencilerini -ki böyle bir uygulamanın Türk Eğitim Sistemi'nde olduğunu hepimiz bilmekteyiz- bu ayrımdan koparabilmelidir. Çünkü sınıfta lider konumundahi öğretmen bilmelidir ki, çalışmayan ögrenci olarak öğretmenin hafızasında yer alan öğrenci, tıpkı sanayide olduğu gibi yaptığı hiçbir ișin patronu tarafından beğenilmediğini bilen mutsuz, huzursuz, isteksiz bir işçi gibi üzerine düşen görevi tam olarak yapamayacaktır. $\mathrm{Bu}$ da süreç bazında ürünün kalitesini etkileyerek kurumun başarısına gölge düşürecektir. O halde eğitimde TKY'nin başarısı da ögretmenin kendisinden beklenen rolleri yerine getirmesine bağlıdır. Geleneksel eğitim anlayışında ögrretmen aktarıcı konumundayken TKY'ye göre öğretmen, öğrenme-öğretme süreçlerini düzenleyen, öğrenciye birey olarak saygı duyan ve öğrenci ile gerekli hallerde birebir temasa geçen rehber konumundaki kişidir. Bir başka deyişle TKY'de ögretmen sınıf ortamında lider konumundadır. Sınıf ortamı bir örgüt olarak ele alındığında TKY için geçerli olan tüm öğelerin orada da geçerli olacağı söylenebilir.

Ögretmen bu yeni sistemde sosyalleşme sürecini diğer deneyimli ögretmenlerle etkileşim içine girerek tamaımlamış profesyonel bir kişidir. Bu da ona bilgilerini diğer öğretmen arkadaşları ile paylaşma, öğrenmeye her zaman açık olma, etkinliklerini sürekli geliștirme, diğer meslektaşlarının fikirlerine saygı duyına vb. profesyonellik özellikleri ile kendine güvenini kazanmasını ve kendi yetersizliklerinin kaynağını bulabilme imkanı verecektir (Glasser, 1999, 196; Balcı, 1993, 32, 43). Kendine güvenen, kendi bilgisinin sınırlarını bilen ögrretmen, öğrencisine ögrenmeyi öğreten, öğrencide merak uyandıran, okul-çevre ilişkisinde yol gösteren, tartışmalı, katılımcı bir ortam yaratarak (Ünal, 1996, 64) ileri seviyede insan gücünün yetiştirilmesinde insan kaynaklarına değer veren, öğrencinin kendini geliștirmesine yardım eden (Atalay, 1996, 606) ve kalite sürecinin beraberinde getirdiği rekabet ortamına öğrenciyi hazırlayan kişidir. Öğretmenin ögreticiliği yalnız kendi çabası ile sınırlı değil, aynı zamanda öğrencinin motivasyonu, öğrenme ortamı ve önceki yıllardaki başarısı vb. ile de bağlantılıdır. Yani ögretmen ögrenci kalitesini oluşturmada diğer ögelerden bağımsız değildir.

$\mathrm{Bu}$ bağlamda eğitim kurumlarında öğretmenlerin; güçlü ve yeterli, istekli ve gayretli, huzurlu ve mutlu, gelişime açık ve kalite inancına sahip olmaları gerekmektedir. Ögretmenin konu hakimiyetine sahip, sınıf içi etkileşimi iyi, öğrencinin güvenine sahip, motivasyonu yüksek olmalı ve sınıfta bir takım ruhu oluşturması gerekmektedir. Ayrıca öğrencilerin değișen ihtiyaçlarını göz önünde bulundurmalı, öğrenciyi bu değişime kanalize edebilmelidir. Bunu yaparken de öncelikle değişimlerden sürekli eğitim kursları ile kendisi haberdar olmalı, gönüllü olarak bunları uygulayabilmelidir. İşte bunları başarabilmesi de TKY'nin sınıf ve okul ortamında başarılması ile gerçekleşecektir (Cafoğlu, 1996, 136-139; Can, 1998, 621). Çünkü öğretmen eski dar kalıplarından sıyrılarak bilgi düzeyini geliştirmeye bașladığı ve bunu sürekli eğitim kursları ile desteklediği zaman öğrenciler nitelikli-kaliteli öğretmene sahip olacaklardır. Bu da sınıf ortamında ögrrencilerin yetiştirilmesinde tecrübe, heyecan ve düşünceleri oranlarında en iyi șekilde eğitilmelerine dönük olarak, belli bir sistematik içinde ilerlemelerini sağlayacak ve öğretmenler de kalite ruhunu ögrencilere, velilere ve bunun sonucunda iş hayatına ve topluma taşıyacaklardır.

Kalite bilinci ile öğretmen, çocuğa gerçek hayatı gösterecek, belli bir bilgi birikimini kazandıracak, okul-aile-çevre ortamlarını bir araya getiren bir katalizör görevi görecek ve çocuğu topluma hazırlayan bir yetiştirici olacaktır (Erkan, 1996, 609-611).

Diğer Çalışanlar: TKY anlayıșına göre eğitim örgütlerinde sadece ögrretmen, öğrenci ve yönetici öğeleri bulunmamaktadır. Bunun dışında destek personel diyebileceğimiz diğer çalışanlar da 
mevcuttur. Bunlar; eğitim araç-gereçlerinden sorumlu olan personel, kütüphane sorumluları, fen laboratuarı bilgisayar laboratuarı sorumluları, hizmetliler, okul-aile birliği üyeleri vb. dir.

Destek personelinin de sürekli gelişim felsefesi uygulanarak yetiştirilmeleri sağlanmalıdır (Cafoğlu, 1996, 114). İç müşteri memnuniyetinin sağlanabilmesi için, çalışan diğer personeli işinden hoșnut, mutlu, huzurlu, zevkle çalıșır hale getirebilirsek bu adımı tamamlamıs oluruz. Ancak yöneticinin diğer çalışanlar üzerindeki etkisi de burada önemli bir konudur. Yönetici bu kișilerin fikirlerine saygı duymalı ve önemsediğini belli etmelidir. Onlara takım çalışmaları ile okul kültürünü benimsetmeleri, öğrenci-öğretmen-veli ve dış çevre ile olan ilişkilerini güçlendirmeleri yönünde destek olmalıdırlar. Ayrıca diğer çalışanların uygulamalarda ögrenci ve ögretmenlerle iç içe olmaları, onların beklenti ve isteklerine cevap vererek ortaya çıkacak hata ve problemleri ortadan kaldırmaları (Cafoğlu, 1996, 111), okulda hizmet verimliliğini sağlayacak ve okul, kalite örgütü olma yönünde ilerleyecektir.

\section{Sonuç}

Günümüzün global dünyasında rekabetin her geçen gün arttığı ve piyasa koşullarında kendine yer edinmek veya edindiği yeri korumak isteyen örgütlerin en üst kademeden en alt kademeye kadar büyük bir inanç ve sabırla TKY anlayışııı uygulamaya çalıştıkları bilinmektedir ki bunu da birçok şirketin (Örneğin; Tat Konserve Sanayi A.Ş., İstanbul Valiliği Özel Kalem Müdürlüğü, Ișıklar Askeri Lisesi, Kuleli Askeri Lisesi, Başkent Üniversitesi Illk ve Ortaöğretim Kurumları Kolej Ayşe Abla Okulları, Özel Irmak Okulları, Eskișehir Merkez Anadolu Teknik Lisesi vb.) ISO 9000 kalite standartları belgelerini alarak başardıklarını görmekteyiz.

Eğitimde de TKY anlayışının uygulamaya geçirilmesinin kaçınılmaz olduğu ortaya çıkmaktadır. Nitelikli çalışanların, nitelikli işgücü ve kaliteli ürünü yaratacağı unutulmamalıdır. Çünkü kalitesiz ürün diğer kalitesiz ürünleri de beraberinde getirmeye devam edecektir. Olumlu bir örgüt kültürü ile ögrencilere benimsetilecek "kalite kültürü" eğitimin diğer basamaklarında ve toplumsal yașamın her alanında (iș hayatı, aile, üst eğitim vb.) istenen hedeflere ulaşmayı kolaylaştıracaktır. Ancak bu istenildiği zaman hemen sonucunu göremeyeceğimiz uzun soluklu bir yapılanma olacaktır. Bu yapılanmada insan kalitesinin iyileştirilerek (oğretmen, yönetici, diğer çalışanlar) sürekli eğitim ihtiyaçlarının gerçeğe uygun bir biçimde belirlenmesi ve bu eğitimlerin olabildiğince sık yapılması eğitim müşterilerinin mutlu kılınması için kaçınılmazdır.

Eğitimde TKY yaklaşımına uygun olarak yönetici, akademik personel, öğrenci ve diğer çalışanlar olarak müşteri memnuniyeti konusuna girdiğimizde her bir müşterinin yapması ve yapmaması gereken işlemlerin olduğu görülmektedir. Okulda bu yaklaşımın uygulanabilirliği öncelikle yöneticinin liderlik konumuyla okulunu idare etmesine, öğretmen, öğrenci ve diğer çalışanlar üzerinde baskı kurmamasına, onları motive ederek iyi bir planlama yapmasına bağlı olduğu anlaşılmakta; öğretmenlerin de klasik baskıcı-öğretici tutumlarından vazgeçmeleri ve sınıflarını bir lider olarak yönetmeleri gerektiği görülmektedir. Öğrenciler ise üzerlerine düşen çalışma görevlerini en iyi şekilde yapmalılardır. Bunun için de okul ortamında her türlü imkan onlara tanınarak, sıcak ve sürekli iletişimle motive edilmelidirler. Bu noktada diğer çalışanların memnuniyeti de göz ardı edilmemelidir. Çünkü TKY sistem geliştirme süreci olarak da anlaşıldığı için sistemin hiçbir üyesi dışarıda bırakılmamalıdır.

TKY'ye göre yönetilen bir okul; başarısızlığın olmadığı, öğretmenlerin danıșman olarak görev yaptıkları, öğrencilerin istedikleri zaman danıșmanlık alabilecekleri ve sistemin tüm süreçlerine katılabilecekleri, sıcak ve destekleyici bir ortama sahip olmalıdır.

\section{KAYNAKÇA}

Aguayo,R. (1994). Dr.Deming Japon Mucizesinin Mimarı. (Y.K.Tunçbilek Çev.). Ankara:Form Yayınları.

Aksu,M.B.(1995). Toplam Kalite Yönetimi. Eğitim Yönetimi Eytepe Dergisi. Bahar sayısı, 1(2). 203-210.

Altıntaş,H. (1998). Eğitim Denetimi ve Toplam Kalite Yönetimi. Çağdaş Eğitim Dergisi. Nisan sayısı, 23(242), 37-39.

Alkan,C. (1994). Eğitim ve Öğretim Araç ve Gereçlerinde Standardizasyon ve Kalite. Türk Milli Eğitiminde Kalite Paneli 15 Nisan (4144). Istanbul: TSE Yayınları.

Așıkoğlu,M. (1997). Japon İșletmecilik Kültüründe Toplam Kalite Yönetiminin Etkileri. Anahtar Gazetesi. Ekim sayısı, 9(106), 10. 
Atalay,S. (1996). Bilgi Toplumu ve Ögretmenlerin Sorunları. Modern Öğretmen Yetiştirmede Gelișme ve İlerlemeler Sempozyum'96 30 Eylül-4 Ekim (603-608). Ankara: MEB Yayınları.

Balcı,A. (1993). Etkili Okul Kuram, Uygulama ve Araştırma. Ankara: Erek Ofset Matbaası.

Balcı,A. (2000). Toplam Kalite Yönetimi. A.Ü.Eğitim Bilimleri Fakültesi Yönetici Adaylarının Eğitim Semineri Ders Notlar 3-21 Temmuz 2000 (65-78). Ankara: A.Ü.Basımevi.

Bayrak,Ç. Ve Ağaoğlu,E. (1998). Illköğretim Okullarındaki Yönetici ve Öğretmenlerin Toplam Kaliteye İlişkin Görüşleri. Eğitim Yönetimi Dergisi. Kıș sayısı, 4(13), 23-37.

Binbașıoğlu,C. (1993). Etkili Öğretim Etkili Okul. Anahtar Gazetesi. Eylül sayısı, 5(57), 14-15.

Bozkurt,R. Ve Asil,N. (1995). Kalite Politikası Oluşturma Süreci. Verimlilik Dergisi. 1995/3. $31-42$.

Bozkurt,R. (1994). Toplam Kalite Yönetim Sistemi. Verimlilik Dergisi. 1994/4, 7-18.

Bozkurt,V. (1997). Eğitimde Toplam Kalite Üzerine Düşünceler. Anahtar Gazetesi. Eylül sayısı, 9(105), 4-22.

Budak,Y.(1999). Eğitimde Toplam Kalite Yönetimi ve Etkili Okulun Gerçekleşmesinde Ögretmenlere Yönelik Hizmet içi Eğitimin Önemi. Çăgdaş Eğitim Dergisi. Şubat sayısı, 24(251),35-38

Cafoğlu,Z.(1995). Okulların Güçlendirilmesi. Ĕgitim Yönetimi Eytepe Dergisi. Son sayı, 1(4),549-556.

Cafoğlu,Z. (1996). Eğitimde Toplam Kalite Yönetimi. İstanbul: Avni Akyol Ümit Kültür ve Eğitim Vakfı Yayınları.

Can,N. (1998). Öğretmen ve Yöneticinin Etkililiği. Eğitim Yönetimi Dergisi. Kıș sayısı, 4(13), 5569.

Ceylan,M. (1997). Eğitimde Toplam Kalite Yönetimi ve Müșteri Memnuniyeti. Eğitim Yönetimi Dergisi. Kış sayısı, I(3), 23-29

Çelik,V. (1996). Eğitim Örgütlerinde Örgütsel Kültür ve Kalite. 5.Ulusal Kalite Kongresi. Istanbul: TÜSIAD - KAL-DER Yayınları. 347350.
Demirdöğen,O. (1994). Kalite Yönetimi Açısından TS-ISO 9000 Serisi ile Deming Felsefesi Arasındaki İlișkilerin Belirlenmesi. Verimlilik Dergisi. 1994/4, 39-56.

Doğan,H. (1999). Kalite Sistemini Uygulayarak Okulların Etkililiğini ve Verimliliğini Geliştirme. Eğitimde Yansımalar V. 21. Yüzyılın Eşiğinde Türk Eğitim Sistemi Ulusal Sempozyumu 25-27 Kasım. Ankara: Öğretmen Hüseyin Hüsnü Tekışık Eğitim Araştırma Merkezi.

Elif, İ. (1999). Toplam Kalite Yönetimi ve ISO 9000 Kalite Güvence Sistemi. İstanbul: Alfa Yayınları. 4. Basım.

Erkan,S. (1996). Geleceğin Eğitim Sisteminde Sınıf Öğretmenliği. Modern Öğretmen Yetiştirmede Ve Gelișme Ilerlemeler Sempozyumu'96 30 Eylül-4 Ekim (609-611). Ankara: MEB Yayınları.

Ergün,O.(1995). Okulda Verimliliği Artırma Yolları. Çağdaş Eğitim Dergisi. Temmuz-Ağustos sayısı, 20(212), 35-37.

Glasser,W.(1999). Okulda Kaliteli Eğitim (U.Kaplan Çev.). İstanbul: Beyaz Yayınları. 1.Basım.

Gürol,M.A. (1993). Örgütlerde "Kalite Tuzağı" Sorunu. Anahtar Gazetesi. Nisan sayısı, 5(52). 18.

Hergüner,G. (1998). Eğitimde Toplam Kalite Uygulamasının Sağlayacağı Yararlar. Eğitim Yönetimi. Kış sayısı, 4(13), 11-21.

Ige,P. (1997). Eğitimde Toplam Kalite Yönetiminin Uygulanmasının Sağlayacağı Yararlar. Anahtar Gazetesi. Subat sayısı, 9(98), 6-7.

Karslı,M.D. (1997). Teknik Eğitimin Yönetimi ve Kalite. Eğitim Yönetimi Dergisi. Illkbahar sayısı, 2(3), 207-218

Kocadağ,D.(1994). ISO-9000 Düşünceler ve Öneriler. Anahtar Gazetesi. Haziran sayısı, 6(66), 4-5.

Korkut,I. Ve Korucu,S. (1998). Cumhuriyetin 75. Yılında Eğitimde Toplam Kalite Yaklaşımı. Milli Eğitim Dergisi. Temmuz-Ağustos sayısı, 66-68.

Köseoğlu,M. Ve diğ. (1994). Toplam Kalite Yönetim Sistemi Uygulamasının Arkasındaki İnsan Faktörü. Verimlilik Dergisi. 1994/4, 1937. 
Köseoğlu,M.(1997). İşletmelerde Kalite Yönetimi ve Verimlilik Arasındaki İlișki. Anahtar Gazetesi. Ocak sayısı, 9(97), 4.

Önder,M.(1998). Örgütsel ve Yönetsel Eklektizm: Toplam Kalite Yönetimi. Amme İdaresi Dergisi. Eylül sayısı, 31(3), 37-74.

Özdemir,S.(1995). Eğitimde Verimlilik ve Toplam Kalite Yönetimi. Eğitim Yönetimi Eytepe Dergisi. Güz sayısı, 1(3), 377-388.

Özdemir,S. (1996). Eğitimde Örgütsel Değişme. Ankara:Pegem yayınları.

Özgen,B. (1998). Eğitimde Standart ve Kalite. Anahtar Gazetesi. Eylül sayısı, 10(117), 4-5.

Peker,Ö.(1994). Toplam Kalite Yönetiminin Eğitim Sistemine Uygulanabilirliği. Amme . İdaresi Dergisi. Haziran sayısı, 2(27), 63-78.

Peker,Ö. (1996). Eğitimde Kalite ve Akreditasyon. Amme İdaresi Dergisi. Aralık sayısı, 4(29), 1932.

Peşkircioğlu,N. (1992). ISO-9000 Kalite Yönetimi ve Güvencesi Standartları. Anahtar Gazetesi. Aralık sayısı, 4(48),4

Sallis,E. (1996). Total Quality Management In Education. 2.Edition. London: Kogan Page Limited. Aktaran Balcı,A. (2000). Örgütsel Gelişme Kuram ve Uygulama. Ankara:Pegem Yayınları.
Serter,N.(1997). 21.Yüzyıla Doğru İnsan Merkezli Eğitim. İstanbul:Sarmal Yayınları. I.Basım.

Şișman,M. (1997). Eğitimde Toplam Kalite Yönetimi ve Kültür. Eğitim ve Bilim. Temmuz sayısı, 21(105), 60-69.

Tok,Ș. (2001). İlköğretim Kurumlarında Toplam Kalite Yönetiminin Uygulanabilirliğine İlișkin Öğretmen ve Yönetici Görüșleri. Eğitim Araştırmaları Dergisi. MART Sayısı 3-4, 110115.
TSE (1995). Orta Öğretimde Kalite ve Standardizasyon Broşürü. Ankara:TSE Yayınları.

TSE (1996). TSE-EN-ISO 9000 Kalite Broşürü. Ankara: TSE Yayınları.

Tunçalp,D. (1994). ISO Standartları Serisi Nedir? Anahtar Gazetesi. Mayıs sayısı, 6(65), 19.

Türkçe Sözlük (1992). Türk Dil Kurumu Yayını.

Ünal,S.(1996). Okul Yöneticileri ve kalite. III.Ulusal Eğitim Bilimleri Kongresi Uludağ Üniversitesi 5-7 Eylül 1996 Bildiri Özetleri (173-174). Bursa.

Ünal,S. (1997). Eğitim-Kalite-İstihdam. Anahtar Gazetesi. Eylül sayısı, 9(105), 5. 